\title{
Bratislava v slovenských filmoch prvej dekády nového milénia Jana Dudková
}

\author{
DUDKOVÁ, J.: Bratislava in Slovak Films of the First Decade \\ of the New Millennium \\ SLOVENSKÁ LITERATÚRA, vol. 68, 2021, no. 3, pp. 325-336 \\ DOI: https://doi.org/10.31577/slovlit.2021.68.3.11 \\ ORCID ID: 0000-0002-3059-3711
}

\begin{abstract}
Key words: Slovak live action
film, Bratislava, urban film, postmodernity, non-places
\end{abstract}

\begin{abstract}
The article deals with the way Bratislava was portrayed in Slovak films with urban settings produced in the first decade of the $21^{\text {st }}$ century and shows how these portrayals changed over this period. Methodologically, the article is based on basic heuristics, i.e. on the analysis of the films themselves. The aim of the paper is to provide a general overview rather than an in-depth analysis of individual pieces. The author draws on her previous research in the area, especially on her Slovenský film vére transkulturality [Slovak film in the era of transculturality; 2011]. By widening the corpus, she tests the relevance of concepts used in film studies at the turn of the millennia ("lifestyle urban film", "non-places", "supermodernity", "postmodernity") for chosen films. The aim of the paper is to map the portrayals of Bratislava and devise their basic typology, while accentuating the narrative of Slovak cinematography as a series of films reacting to each other, gradually shifting their focus from the historical city centre to the places on the right side of the Danube (e.g. Vel'ký rešpekt [Big respect], Bratislavafilm) and subsequently to other Slovak regions and towns.
\end{abstract}

Klúčové slová: slovenský hraný film, Bratislava, mestský film, postmodernita, nemiesta 

prvej dekády nového milénia je, že ide o obdobie, ked'v slovenskej kinematografii dominujú diela odohrávajúce sa práve v Bratislave. Otázkou však ostáva, do akej miery sa $\mathrm{v}$ nich obrazy Bratislavy riadia podobnými axiómami a do akej miery sú tieto obrazy od seba nezávislé. Pri aktuálnom vymedzení základnej typológie bratislavských prostredí môžu byt' východiskom staršie pojmy spájané s obrazmi Bratislavy vo filme.

Jedným z prvých pojmov, ktorými sa slovenská filmová kritika a história pokúsila definovat' nový druh fokusu na Bratislavu, bol „lifestylový mestský film“. Podl'a filmového historika Martina Šmatláka sa na konci devät'desiatych rokov 20. storočia a v prvej dekáde nového milénia v slovenskej kinematografii formuje nový trend, ktorý Šmatlák podla vzoru Juraja Malíčka (Malíček 2004) nazýva bud' „popom po domácky“, alebo práve „lifestylovým mestským filmom“. V Šmatlákovom podaní ide o trend, ktorý sa nepokúša „zobrazit' aktuálny ani historický spoločenský kontext, ani sa neponára do ,medzikultúrneho' dialógu“. Nekladie si za ciel' „prinášat' osobnostné svedectvo o svete, spoločnosti či človeku“, ale má „zaujat' najmä pocitom, zabavit' niektorými žánrovými prvkami, alebo ponúknut' na plátne známe reálie a motívy ,novej doby““, pričom dôraz kladie na ,,klipovité či obrazovo segmentované rozprávanie, ako aj na viaceré vonkajškové znaky súčasného sveta, akými sú najmä autá a drogy, biznismeni a bary, všadeprítomná telka, dabing či reklama“ (Šmatlák 2008:145). Predzvest'ou trendu je podla M. Šmatláka debut Štefana Semjana Na krásnom modrom Dunaji (1994), ale i Hazard (1995) Romana Petrenka, typickými príkladmi sú $O$ dve slabiky pozadu (réžia Katarína Šulajová, 2004), Polčas rozpadu (réžia Vladimír Fischer, 2007), Zostane to medzi nami (réžia Miroslav Šindelka, 2003) či Vadínevadí (réžia Eva Borušovičová, 2001).

V zásade ide o pomerne rôznorodé filmy, ktoré sa však zhodou okolností všetky odohrávajú v Bratislave a pre ktoré je charakteristický, okrem prvkov identifikovaných M. Šmatlákom a J. Malíčkom, aj záujem o rozklad rodiny a konceptu vernosti. $V$ tomto zmysle sa však $\mathrm{k}$ trendu pripája aj rad d'alších variácií na tému života v hlavnom meste. Niektoré z nich do Šmatlákom a Malíčkom popísaného druhu nepatria, pre pomerne vel'kú čast' z nich sa však dá použit' pozorovanie Ewy Mazierskej a Laury Rascaroli, ktoré do oblasti filmových štúdií priniesli dovtedy takmer nepertraktovanú tému postmoderného európskeho filmu a postmodernity v európskom filme. Pod „postmodernitou“ chápu Mazierska a Rascaroli kultúrny, ekonomický a socio-politický stav

„charakterizovaný takými vzájomne prepojenými fenoménmi, ako sú zvyšujúca sa postindustriálna a na služby orientovaná ekonomika so všetkými jej charakteristikami a dôsledkami: nárastom hi-tech a zábavného priemyslu; nárastom sociálnej polarizácie; fragmentáciou mestského habitusu; kompresiou priestoru a času vytvorenou informačnou revolúciou; narastajúcim kozmopolitizmom a multietnicitou životného prostredia; globalizáciou kultúry a stieraním hraníc medzi ,vysokou' a ,nízkou kultúrou““ (Mazierska - Rascaroli 2003: 9).

Pod pojmom „postmoderný film“ následne chápu film charakterizovaný v intenciách Fredrica Jamesona (Jameson 2016) vyhladením historickej minulosti a „silnou nostalgiou, za ktorou sa skrýva nemožnost' porozumiet' minulosti 
ukrytej za reprodukciou stereotypných obrazov“ (Mazierska-Rascaroli 2003:9).

Postmoderný film d'alej súvisí s fenoménmi ako pastiš, sebareflexivita, intertextu-

alita a časopriestorová kompresia či až sklon k zdôrazňovaniu večnej prítomnosti (Mazierska - Rascaroli 2003: 9). Podstatným prínosom autoriek je upozornenie na platnost' týchto všeobecne známych charakteristík a fenoménov nielen v severoamerickom filme, ale aj v kinematografiách Západnej i Východnej Európy.

\section{Bratislava medzi postmodernitou a nadmodernitou}

Slovenské filmy prvej dekády nového milénia, v ktorých Bratislava tvorí významotvornú kulisu a určuje aj siet' špecifických vztahov medzi postavami, môžu byt' materiálom pre overenie platnosti definície lifestylového mestského filmu od M. Šmatláka, ale aj otázky ich poetologického zaradenia do skupiny postmoderných filmov.

Dej režijného debutu E. Borušovičovej Vadí nevadí, ktorý bol M. Šmatlákom označený za jeden z prvých lifestylových mestských filmov, sa na rozdiel od budúcich príkladov tohto trendu odohráva najmä v klaustrofobických prostrediach nočných klubov a ulíc. Práve nočný život je pritom možné považovat' za jeden z hlavných prejavov mestského charakteru (nielen) filmových prostredí, odlišujúcich mesto od predmestia či vidieka (bližšie napríklad Gottdienter-Budd 2005:10). Okrem toho Vadí nevadí vnáša do národnej kinematografie prvky dovtedy málo využivaných žánrov krimifilmu a romantickej komédie. Intertextuálnu povahu zdôrazňuje napríklad aj množstvom filmových plagátov, upozorňujúcich na inšpiračné zdroje (podobný princíp je využitý vo filme $O$ dve slabiky pozadu). Skôr ako o koherentný žáner ide však vo Vadí nevadí, podobne ako v jeho svojho druhu predchodcovi Na krásnom modrom Dunaji, o stieranie hraníc medzi životom a (v tomto prípade) filmom. V oboch filmoch sa objavuje motív dvojitých identít, maskovania, zmien vedomia pod vplyvom drog, čo pomáha (v kontraste $\mathrm{s}$ faktom, že žiadna z postáv neopúšta hranice Bratislavy) vytvorit' nielen efekt spriaznenosti s postmoderným stavom, ale najmä efekt izolácie v akomsi druhu vnútorných azylov, kde práve intertextuálne vztahy predstavujú dominantnú formu „migrácie“ smerom na Západ. Kým film Š. Semjana Na krásnom modrom Dunaji využiva odkazy na nové vlny, tvorbu Andyho Warhola a nezávislý americký film, Vadí nevadí sa prostredníctvom plagátov hlási najmä k hollywoodskej produkcii a nezávislej hudobnej a rozhlasovej kultúre. Podobnost' hlavného protagonistu s Jimom Morrisonom podčiarkuje napríklad jeho spriaznenost's fiktívnou rozhlasovou stanicou Rádio Európa, ktorá tu funguje práve ako metafora vnútorného azylu bratislavských intelektuálov a odkazuje na nezávislú rozhlasovú stanicu Ragtime, v dobe nakrúcania filmu už zaniknutú (ohrozenie protagonistu mafiánmi je prostredníctvom jeho krvi stekajúcej po plagáte J. Morrisona pripodobnené aj k ohrozeniu nezávislosti samotnej rozhlasovej stanice).

Napriek kozmopolitným názorom postáv a reálnej možnosti cestovat'sa väčšina postáv filmu pohybuje len v striktne vytýčenom okruhu kaviarní v historickom jadre Bratislavy (migrácia je spojená len so zmienkami o neprítomných postavách, výlučne však v kontexte úteku pred zákonom alebo nomádskeho životného štýlu). Vadí nevadí popri pokuse o reflexiu postmodernizmu upozorňuje teda aj na potrebu vnútornej izolácie budovanú umelcami a intelektuálmi v nehostinnej dobe mečiarizmu. Vzhl'adom na dobu vzniku filmu - niekol'ko rokov 
328 po konci tretej Mečiarovej vlády - to možno považovat' za prejav solidarity medzi absolventmi a pedagógmi Vysokej školy múzických umení ako istej bašty nesúhlasu s Mečiarovou vládou v devät'desiatych rokoch. Napriek anachronickosti tejto myšlienky je solidarita skutočne podporená obsadením viacerých spolužiakov i pedagógov režisérky filmu do hlavných i epizódnych rolí.

Naopak, debut Vladimíra Adáska Hana a jej bratia (2001) nebol priamo zaradený medzi lifestylové mestské filmy, hoci má s nimi spoločný cit pre post-

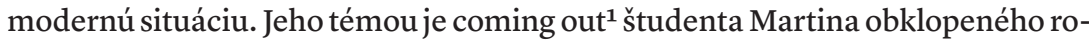
dinou, v ktorej tri švagriné čelia neverám či alkoholizmu manželov, no existenciu transgenderovej kabaretnej speváčky Hany alias strýka Tonyho pred mladým Martinom taja. Film bol z väčšej časti nakrúcaný v úzkom okruhu historického centra mesta, napríklad v okolí Kapitulskej ulice či Academie Istropolitany, v ktorej bola v tom čase umiestnená Vysoká škola múzických umení (niektorí pedagógovia školy sa objavujú aj vo filme, napríklad Marta Žuchová a Juraj Mojžiš). Hereckým prejavom, akciami a interakciami nadväzuje film na poetiku raných filmov Juraja Jakubiska a Ela Havettu, čím potvrdzuje spätost' postmodernej kinematografie s tou modernou. Využiva prvky absurdity i surreálna, hlavné postavy vytŕha z akýchkolvek pracovných súvislostí (výnimkami sú postavy epizódne ako lekárnik, ktorý sa pokúša zviest' Martinovu sesternicu Hemu, alebo záhadný Duga, ktorý alternatívnymi metódami lieči jeho matku). V súčasnej slovenskej kinematografii ide - popri Čase grimás (réžia Peter Dimitrov, 2009) o živote Franza Xavera Messerschmidta - o ojedinelé pripomenutie stredovekého historického jadra mesta, nadväzujúce čiastočne na Jakubiskovu lokalizáciu časti deja filmu Vtáčkovia, siroty a blázni (1969) práve do okolia Academie Istropolitany, ale i vtedy ešte relatívne zachovanej Vydrice. Napriek dôrazu na historickú architektúru je podstatným prvkom filmu izolácia jeho postáv od spoločenských, politických či historických súvislostí, ale tiež dôraz na vol'né vztahy (Hema) či queer identitu (Hana, Martin a Hanin okruh transgenderových tanečníc a „obdivovateliek“). Týmto sa zdôrazňuje aj adaptácia Bratislavy na postmoderný stav, staré jadro mesta je úzko prepojené s celkom novými, najmä rodovými a sexuálnymi hodnotami.

Len rok po uvedení filmov Hana a jej bratia a Vadí nevadí, v ktorých postavy trávia čas v okruhu historického jadra mesta a takmer ho neopúštajú, mal premiéru Dážd' padá na naše duše (réžia Vladimír Balco, 2002). V jeho prípade je dôraz položený na dichotómiu mesta a jeho okolia, ktoré konotuje slobodu a spätost' s prírodou. Protagonistami filmu sú väzeň pokúšajúci sa o útek a jedenástročné dievča zanedbávané rozvedenými rodičmi (otec neplatí alimenty a nemá ani jej najnovšiu fotografiu, hluchonemá matka strieda milencov). Kika sa v úvode filmu stane najprv rukojemníčkou, neskôr však kamarátkou Joka, muža slovenskej matky a juhoslovanského otca, ktorý vyrastal medzi sirotincami a polepšovňami a momentálne je na úteku z väzenia. Vzhl'adom na situáciu, v ktorej sa dvojica ocitla, je Bratislava vykreslená ako nehostinná džungl'a, v ktorej verejné inštitúcie nechránia práva slabých, rodiny sa rozpadajú, škola i väzenie sú miestom šikany a mafiáni spolupracujú s políciou. Z tohto prostredia unikajú dvaja protagonisti do lužných lesov okolo Dunaja a pril'ahlých chatiek pri vode. Zábery na Dunaj a jeho plynutie

1 Coming out - vývinový proces, pri ktorom človek rozpoznáva a akceptuje svoju menšinovú emocionálnu a sexuálnu orientáciu alebo sexuálnu identitu. 
vytvárajú leitmotív symbolizujúci túžbu po úniku i súlade s prírodou (dievča ob- 329 jíma stromy, dvojica tancuje v daždi a kúpe sa v rieke). Okolie Dunaja pri Starom moste (s Bratislavským hradom v pozadí) zas umožňuje l'ahkú identifikáciu miesta deja. Dunaj je útočiskom, ale zároveň jednou z dominánt mesta a v neposlednom rade i dopravnou tepnou, prostredníctvom ktorej je možné doslova odplávat' preč od štátnych inštitúcií - Joko plánuje a v závere aj uskutoční útek z krajiny lod'ou. Ako píše Foucault, „lod' je plujícím kusem prostoru, umístěním bez místa [...] heterotopie par excellence" (Foucault 2003: 85-86). Obrazom nákladnej lode na Dunaji film začína i končí. Postrelený Joko padá zo Starého mosta do rieky, no pred očami Kiky sa neutopí, ale objaví sa práve na nákladnej lodi.

Na rozdiel od filmu Dážd'padá na naše duše, ktorý je zasadený do tradičnejšej dichotómie mesto - príroda, debut K. Šulajovej $O$ dve slabiky pozadu patrí medzi typické lifestylové mestské filmy. Termín použil J. Malíček práve v súvislosti s týmto filmom. Zároveň však ide o jeden z mála súdobých filmov, v ktorom sa bratislavská identita aj verbálne priznáva. Ked'sa protagonistka filmu zoznámi so svojím budúcim parížskym milencom, explicitne uvádza, že je z Bratislavy. Rozlietaná študentka umenia živiaca sa dabingom a účinkovaním v reklamách, bývalá detská herecká hviezda Zuza, sa pohybuje medzi uličkami Starého mesta, fakultou a dabingovým štúdiom, ale nemá problém ani spontánne nasadnút do auta a odviezt' sa na vernisáž do Paríža. Práve jej parížska avantúra predstavuje podklad pre nepriame vizuálne porovnanie dvoch miest: fotogenickost' Bratislavy vo filme nezaostáva za fotogenickostou Paríža, obom mestám sú venované klipovité zostrihy dominánt, charakteristické pre koncipovanie miest ako značiek, brandov, v prípade Bratislavy tak napríklad niekol'kokrát vidíme ozvláštňujúce zábery na kaviareň UFO nad Mostom SNP. Bratislavskú identitu neurčujú len architektonické pamiatky, je poňatá ako postmoderne kozmopolitná a premenlivá, no tiež tradične multikultúrna: Zuzina babička je napríklad Mad'arka, ktorá v mladosti slúžila v židovskej rodine. Zato Zuzin priatel' študuje čínštinu a zoznamuje ju s majitel'om skladu s čínskym tovarom, pristahovalcom usadeným v meste. Stará predvojnová Bratislava sa stretáva s novou, mesto je však zároveň zasadené do kontextu takzvaného „druhého sveta“, je súčastou bývalého socialistického štátu, jej obyvatelia si ešte stále spomínajú na Zuzu ako hviezdu normalizačného detského seriálu a na socialistickú minulost' odkazujú aj niektoré vizuálne motívy, napríklad vel'koplošné mal'by na stenách domov, takzvané murály, okolo ktorých Zuza beží na ceste od jednej povinnosti k druhej. Bratislava je teda útočiskom migrantov z „tretieho sveta“ (konkrétne z Číny), no to ju nepovyšuje na úroveň prvého sveta. Vidno to najmä vo chvíli, ked' sa Zuza, opustená milencom, stretáva s chlapcom tmavej pleti v uliciach Paríža a so slzami v očiach mu po slovensky rozpráva rozprávku o šedej myške, ktorá sa nechala zožrat' mačkou. Zuza, identifikujúca sa so šedou myškou z bývalej socialistickej krajiny, sa musí vrátit' domov.

Ďalším filmom, ktorý M. Šmatlák zaraduje do skupiny lifestylových mestských filmov, je Zostane to medzi nami. Nejde však o film, ktorý by sa zaoberal bratislavskou identitou v kontexte jej porovnávania so svetovými metropolami, akou bol vo filme $O$ dve slabiky pozadu Paríž. Nie sú tu už ani úvahy nad miešaním konceptov „prvého“, „druhého“ a „tretieho sveta“ či zdôrazňovanie historickej pamäti mesta.Zostane to medzi nami nie je do takej miery postmoderným filmom, naopak, jeho dej sa takmer celý odohráva v priestoroch, ktoré podl'a vzoru Marca 
330 Augého môžeme nazvat' nadmodernými nemiestami (non-lieux). Nemiesta sú priestory, v ktorých sa už identita neformuje vo vzt'ahu k druhému ako subjektu, je to identita objektu, ktorá sa potvrdzuje v hraničných bodoch nemiest rôznymi typmi dokladov (občiansky preukaz, platobná karta, letenka). Letiská, viacprúdové dial'nice či nákupné centrá sú podl'a Augého typickými nemiestami. Mizne v nich vztah $\mathrm{k}$ druhému aj $\mathrm{k}$ historickej identite miesta a zdôrazňuje sa vztah $\mathrm{k}$ „zmluvnej osamelosti“ a ku komunikácii so systémom textov a prostredníctvom nich so systémom inštitúcií, právnických osôb a nadnárodných spoločností (Augé [Ože] 2005: 90 a nasledujúce).

Vo filme Zostane to medzi nami sa budúci manželia Danica a Michal st'ahujú do bytu „tretieho tisícročia“ s vel'kou presklenou obývačkou a najnovšími technológiami. Obrazy ich bytu sa striedajú s priestormi neosobného loftu Danicinho milenca DJ Tomáša $H$, ale i s priestormi nákupného centra s kaviarňami, s obchodmi a so športoviskami, so zábermi na jazdy autom po dial'nici či so zábermi podjazdov a nadjazdov, prípadne so zábermi rozhlasového štúdia, odkial' pravidelne vysiela DJ Tomáš. Vel'ká čast' týchto priestorov patrí do kategórie nemiest, d'alšia čast' aspoň zdôrazňuje neosobnost' ako základnú charakteristiku koncepcie priestorov $\mathrm{v}$ tomto filme. Jediná postava, ktorá býva $\mathrm{v}$ pomerne tradične zariadenom panelákovom byte, je bývalá priatel'ka DJ-a Tomáša.

Priestory, ktoré by odkazovali na históriu Bratislavy-presne v logike augéovskej nadmodernity-absentujú. Nejde o postmodernú koncepciu priestorov, kde ešte pretrváva nostalgia (porovnaj Mazierska - Rascaroli 2003: 9). Vo filme prevažujú chladné farby a pološero, signifikantnú úlohu zohrávajú zábery cez sklo či odrazy na sklených povrchoch, symbolizujúce odcudzenost' a povrchnost' medziludských vztahov. V tomto kontexte výber nákupného centra ako dominantného priestoru filmu nie je náhodný. Prostredie nového nákupného centra je rovnako ako dial'nica typickým nemiestom, paradoxne však práve $\mathrm{v}$ jeho priestoroch postavy skúšajú nadviazat' vzájomnú komunikáciu: na tomto mieste sa stretne Tomáš so snúbencami Danicou a Michalom, sem príde Danica porozprávat sa o Tomášovi s jeho bývalou láskou, tu sa stretávajú tri páry pri hre squashu, sem pozve Tomáš na kávu poslucháča svojej rozhlasovej relácie. Bratislava ako mesto je rozpoznatel'ná najmä prostredníctvom obrazov ciest okolo Mosta SNP a nákupného centra Aupark. Umiestnenie bytov, v ktorých žijú postavy, je bližšie nešpecifikované, stále však ide o jeden z filmov, v ktorých je transformácia bratislavskej identity klúčovou témou. Bratislava je prezentovaná, parafrázujúc Augého, doslova ako miesto „zmluvnej osamelosti“, bez väzieb na minulost' a bez blízkosti a skutočnej kultúrnej výmeny v medziludských vzt'ahoch.

Naopak, dej filmu Tango s komármi (réžia Miloslav Luther, 2009) je rozložený medzi Španielsko, Bratislavu a Brno, kde jedna z postáv pracuje ako klinická psychologička. Postavy sa však ocitajú aj v Prahe či Hamburgu - väčšia čast' z nich sú emigranti alebo pracovní migranti. Samotná Bratislava je v duchu tejto myšlienky zobrazená ako križovatka národov: ocitá sa tu ukrajinský Rusín Bohdan i jeho synovec, ktorý sa pokúša emigrovat' do Kanady, bulharská prostitútka, naznačená je prítomnost' ázijských kultúr v zábere na čínsku reštauráciu. Bratislava je miestom, kde si jedna z hlavných postáv, dcéra rozvádzajúcich sa rodičov Tina Demanová, chce založit' rodinu (a kde zatial' žije v provizórnych podmienkach prerábaného bytu), ale aj miestom prechodného pobytu pre postavy jej otca 
Demana a muža najatého na jeho sledovanie, herca Rudiho Sklenku (obaja sa ubytujú v hoteli Devín, odkial' majú dobrý výhl'ad na Bratislavský hrad). Vo filme dominuje situovanie deja do ulíc miest, prípadne do priestorov ako hotel či byt v rekonštrukcii, dominuje teda koncepcia miest ako prechodných zastávok, často na ceste k lepšiemu životu. Táto myšlienka je podporená aj obrazmi rybačky ukrajinských pristahovalcov za mestom: väčšina postáv sa nachádza v stave čakania či očakávania, od tehotnej Tiny Demanovej, jej rodičov, ktorí čakajú na rozvod, Rudiho Sklenku, ktorý je angažovaný Demanom i jeho milenkou, aby pri tomto rozvode asistoval, či dvoch ukrajinských migrantov, ktorí čakajú na výplatu (Bohdan) alebo odsun z krajiny (Bohdanov synovec).

Jednou z prvých sociálnych drám, nakrútenou ešte v nadväznosti na poetiku mestského filmu, bol film Malé oslavy (réžia Zdeněk Tyc, 2008). Neskoršie filmy z cyklu slovenských sociálnych drám sa však už z väčšej časti odohrávali mimo hlavného mesta, $\mathrm{v}$ regiónoch alebo aj mimo krajiny. ${ }^{2} \mathrm{~V}$ Malých oslavách poukazujú na umiestnenie v Bratislave hned'úvodné zábery na Bratislavský hrad s mostom Apollo v popredí. Inak sa však väčšia čast' deja odohráva na nemenovanom sídlisku, kde chlapci hrajú futbal na streche socialistickej garážovej výstavby, v ubytovniach a súkromných príbytkoch, vo vozidlách MHD a na jej zastávkach. Bratislava je zobrazená ako akékol'vek mesto, kde ekonomická kríza existenčne ohrozuje malých podnikatel'ov, v tomto prípade slobodnú matku, kaderníčku Magdu, ktorá kvôli výpalníkom prichádza o prácu i domov. Koprodukčný charakter filmu je naznačený postavou Čecha vracajúceho sa z kanadskej emigrácie, multikultúrny charakter mesta je zas signalizovaný postavou Magdinej kamarátky mad'arského pôvodu, ktorá chodí na hodiny salsy vedené mulatským učitel'om.

V tom čase relatívne nový most Apollo je v úvode i počas filmu niekolkokrát využitý aj na lokalizáciu deja vo filme Ženy môjho muža (réžia Ivan Vojnár, 2009). Využíva však nočné zábery, v ktorých je Bratislavský hrad nezretel'ný. Ked' sa následne macedónske dievča, ubytované u protagonistky filmu Very, presúva k bytu svojho krajana, namiesto bratislavských reálií je využité okolie stanice pražského metra. Miesto diania je tak zámerne zahmlené, divák nevie, kde sa nachádza byt hlavných postáv, v ktorej krajine pôsobí reklamná agentúra Verinho manžela, kde sa stala vražda modelky, ktorá mala v ním režírovanej reklame hrat'. Vraždu vyšetruje slovensko-český pár, Verin manžel je tiež Čechom pracujúcim v slovensko-českom tíme. Dvojjazyčnost' filmu motivovaná jeho koprodukčným charakterom je však doplnená aj postavami japonských objednávatel'ov reklamy či macedónskeho dievčata-siroty, ktoré sa ubytuje u ústredného páru. $\mathrm{V}$ zásade ide o trocha umelé znaky multikulturality: hlavné postavy sa totiž utápajú v kríze stredného veku, ich cielom nie je spoznat' druhého. Stret kultúr zdôrazňuje skôr postmoderný charakter filmu i reálií, ktoré zobrazuje, ale aj nesúmeratelnost' stredoeurópskej skúsenosti so skúsenostami potenciálne vojnových zón, stelesnenými v postave Macedónky Liany. Ked'ju Vera pozve do svojej upadajúcej televíznej šou, aby rozpovedala svoj príbeh, zaskočené dievča zostane mlčat'a v závere filmu sa napokon rozhodne vrátit' sa do vlasti.

2 Lištičky (réžia Mira Fornay, 2009), Dom (réžia Zuzana Liová, 2011), Až do mesta Aš (réžia Iveta Grófová, 2012), Môj pes Killer (réžia M. Fornay, 2013), Zázrak (réžia Juraj Lehotský, 2013), Koza (réžia Ivan Ostrochovský, 2015), Eva Nová (réžia Marko Škop, 2015). 
Na multikulturalitu Bratislavy v novom miléniu často upozorňujú práve voslávnom chráme), ktorú moderátorka Vera napriek svojmu menu už stráca.

Nesúmeratel'nost problémov Bratislavčanov a pristáahovalcov je podobným spôsobom zdôraznená vo filme Polčas rozpadu. Ako zrkadlo bratislavskej identity slúži postava arménskej čašníčky a speváčky prezývanej Madonna, ktorá v závere utešuje paralelne svoju sestru, nelegálnu utečenku znásilnenú vojakmi pred očami svojho priatel'a, a protagonistu Viktora, ktorý sa ocitol „len“" záchvate sebalútosti po krachu svojimi neverami už dlhší čas ohrozovaného manželstva.

Umiestnenie v Bratislave je vo filme priznané prostredníctvom známych scenérií v okolí Dunaja a v historickom centre mesta (kaviareň Verne, Hviezdoslavovo námestie, most Apollo, pravý breh Dunaja pri Sade Janka Krála a podobne). Hned úvodnýzáber, v ktorom kamera krúži okolo polodetailu na Viktora, zachytáva Dóm svätého Martina v pozadí, nasleduje panoramatický záber na okolie Mosta SNP. Film je koncipovaný ako retrospektíva, pričom úvod vyznačuje hranice životného sveta protagonistu i jeho záverečný pocit straty orientácie. Následne sa však zoznamujeme s protagonistovou svokrou, ktorá sa usadí v prostredí akejsi banky a pýta si rakvičky, pretože si ešte pamätá cukráreň na tom istom mieste. Prostredie Bratislavy a jeho premenlivost'v čase sú teda hned'v úvode určené ako formotvorné, zloženie postáv je však podobne ako v dalších dobových filmoch slovensko-české (manželka muža z úvodu filmu i jeho svokra sú Češky).

Naopak, Bratislava je koncipovaná prevažne ako monokultúrne miesto čakania vo filme Nebo, peklo... zem (2009) Laury Sivákovej. Jej hrdinke sa črtá prvé svetové angažmán, na ktoré sa však nemôže pripravovat', pretože si nešt́astnou náhodou poraní nohu. Rozpadá sa jej vztah, nájde si milenca, stará sa o jeho dcéru a pokúša sa ju skontaktovat' s matkou, ktorá ju opustila, utešuje vlastnú matku trpiacu otcovými neverami a stráca milovaného brata. Film L. Sivákovej sa odohráva najmä v nešpecifických priestoroch súkromných bytov, rodinných domov, baletnej telocvične, divadla či prírody za mestom. Dôraz je položený na dozrievanie protagonistky cez neuspokojivé vztahy s mužmi, ktorí symbolicky brzdia jej umelecký rozlet.

Bratislavské reálie sú priznané až v poslednej štvrtine filmu, ked' protagonistku vidíme pred Prezidentským palácom či v nákupnom centre Aupark. Hoci sa dej odohráva v lokalizačne neutrálnych prostrediach, identifikácia Bratislavy je zámerne skoncipovaná tak, aby pripomínala jej svetový charakter. Hrdinka čaká na svoju zverenkyňu pred fontánou v tvare zemegule, schodisko v nákupnom centre má typickú architektúru nemiest. Prvé priznanie Bratislavy ako miesta deja zdôrazňuje otvorenost' Bratislavy voči svetu, najmä však postupné otváranie sa protagonistky možnostiam mimo jej mileneckých vztahov (fontána je zvolená ako miesto stretnutia medzi dcérou protagonistkinho milenca a jej matkou-stretnutia, ktoré iniciuje práve protagonistka krátko predtým, ako sa napokon s milencom 
rozíde). Bratislavská identita je teda súčasne priznaná aj povýšená na globálnu, 333 čo korešponduje s postupným dozrievaním protagonistky $\mathrm{k}$ možnosti vycestovat' z krajiny za svetovou kariérou. V závere filmu sa po niekol'kých rokoch vracia do mesta lietadlom a vstupuje doň cez most Apollo už ako uznávaná umelkyňa.

\section{Koniec lavého brehu Dunaja}

Uvedené filmy sa väčšinou sústred'ovali na historické centrum Bratislavy na l'avom brehu Dunaja, pričom pravý breh znázorňovali obvykle len v blízkosti rieky. V roku 2008 bol však uvedený film Viktora Csudaia Vel'ký rešpekt a v roku 2009 aj Bratislavafilm Jakuba Kronera. Obidva filmy presúvajú pozornost'zo života v centre mesta k jeho sídliskovým subkultúram, i ked' postavy sa v oboch prípadoch stále pohybujú aj v blízkosti centra - najmä však na pravom brehu Dunaja. Zatial' čo Vel'ký rešpekt je formálne pomerne konvenčným rozprávaním o vol'nom čase mladých ludí z Petržalky, vrátane odkazov na skupiny venujúce sa drobnej kriminalite, Bratislavafilm uplatňuje v domácich pomeroch invenčnú poetiku inšpirovanú hip-hopom a amatérskym videom.

Film je rámcovaný príchodom naivného mládenca do Bratislavy, kde sa chce osamostatnit' od rodičov a nájst' si bývanie a prácu. Negatívne stereotypy o namyslených a l'stivých Bratislavčanoch mládenec odmieta, no film ukazuje ich platnost' na príklade niekol'kých paralelných príbehov, odohrávajúcich sa počas jedného dňa a noci. V úvode tiež využíva pre dovtedajšiu slovenskú kinematografiu netypický dynamický zostrih záberov nakrúcaných roztrasenou, akoby ručnou kamerou, prípadne z výrazných nadhl'adov a podhladov. Dej je následne prerušovaný ukážkami koncertov súdobej hip-hopovej scény, zábery na architektonické dominanty Bratislavy strieda so zábermi bratislavských sídlisk a života na sídliskách.

Hoci režisér používa príbuzné identifikačné znamenia Bratislavy ako vyššie uvedené filmy (zábery na UFO kaviareň a Most SNP, Bratislavský hrad, okolie nákupného centra Aupark), kombinuje ich so zábermi na panelovú zástavbu. Väčšina postáv žije v Petržalke, niektoré uvádzajú ako svoje bydlisko Vrakuňu. Rodinné i partnerské vzt'ahy sú u všetkých narušené, postavy prechádzajú rozchodmi či odhaleniami nevery. Navyše, podl'a filmu kvitne v Bratislave obchod s drogami a uplatňujú sa v nej mafiánske praktiky ako vydieranie a ponižovanie obetí.

Čast' deja sa síce odohráva v centre mesta, vel'ká čast' je však situovaná na ulice sídlisk, pričom životný štýl protagonistov približuje bratislavské sídliská ku getám svetových vel'komiest. V úvode je navyše Bratislava prostredníctvom hudby s orientálnymi motívmi prirovnaná aj k vel'komestu tretieho sveta. Zábery na Bratislavský hrad, Slavín, Dóm sv. Martina, ale i panelovú zástavbu a zanedbané interiéry bytov sú nakrútené ako amatérske filmárske pohl'adnice a za sprievodu štylizovaných zvukov pripomínajúcich bečanie oviec či kvákanie žiab je Bratislava prezentovaná práve ako metropola tretieho sveta.

Filmy Vel'ký rešpekt a Bratislavafilm sa dajú vnímat' ako reakcie na prevahu filmov odohrávajúcich sa na l'avom brehu Dunaja počas väčšej časti prvej dekády nového milénia. Ďalším typom reakcie sú však filmy odohrávajúce sa prevažne v mimobratislavských regiónoch. V roku 2009 bol napríklad uvedený film Vladimíra Balka Pokoj v duši, odohrávajúci sa na samote v regiónoch, kam sa protagonista vracia po rokoch strávených vo väzbe. Prostredie Bratislavy je v ňom využité 
334 len marginálne a v súvislosti s pochybnými podnikmi, ktoré sa organizujú práve v nej. Jediné bratislavské priestory, ktoré vidíme, sú kancelárie s exkluzívnym výhl'adom na Bratislavský hrad. Práve tie umožňujú l'ahkú identifikáciu lokality.

O presun pozornosti na prostredia v regiónoch sa pokúsil už v roku 2007 Robert Šveda v poviedkovom filme Démoni (2007). Prvá z poviedok, Soňa, sa však odohráva v Bratislave, najmä v okolí Dunaja (na lodi alebo v blízkosti Starého mosta), ale aj na detskom oddelení nemocnice a v prostredí televízie Markíza, kde sa protagonista filmu snaží zapôsobit' na mladú ženu. Poviedka je len úvodom k téme zradenej lásky, ktorú d'alšie dve poviedky spracúvajú už v prostredí Červeného Kláštora, respektíve Banskej Štiavnice. Film sa pokúša priniest' do národnej kinematografie viac dôrazu na krehkost' intimity a lásky, pričom originálnym spôsobom spracúva aj tému homosexuálnej lásky v tretej poviedke Klára. Jeho odlišnost' vo vzt'ahu k dominujúcemu trendu mestského lifestylového filmu je zdôraznená už v prvej poviedke, kde sa akcia redukuje na pomalé zvádzanie. Hlavné mesto a súkromná televízia tu nepôsobia ako znaky modernity, postmodernity či nadmodernity, ale sú zobrazené z pohl'adu rodiacej sa prítažlivosti medzi dvomi mladými lud'mi. Nabúranie dominantného obrazu Bratislavy je tak aj úvodom k objaveniu (regionálnych) prostredí, ktoré dovtedy v národnej kinematografii absentovali, akými sú zanedbaná psychiatrická liečebňa či turistické chatky mimo sezónu.

\section{Záver}

Analyzované filmy predstavujú odlišné prístupy k mestskému filmu. Bratislava sa v niektorých z nich javí ako miesto dočasného pobytu ako vo filme Tango skomár$m i$, kde je dôraz položený na striedanie mestských prostredí a kde sa príležitostní návštevníci stretávajú s ekonomickými alebo politickými migrantmi. Vo filme Vadí nevadí si zas mladí ludia hladajú vnútorné azyly kozmopolitizmu v situácii, ked'sami neopúštajú hranice mesta. Zostane to medzi nami zdôrazňuje prostredia nadmodernity a nemiest, v ktorých sa individuálna i kolektívna identita strácajú v neosobnom kontakte s nadnárodným trhovým systémom. Dážd'padá na naše duše prezentuje Bratislavu ako nehostinné prostredie, nepriatel'ské k vyvrhel'om spoločnosti, ktoré poludštuje len prítomnost' Dunaja ako tepny úniku. O dve slabiky pozadu konfrontuje staršiu a novšiu podobu bratislavskej multikulturality a s typicky postmodernou nostalgiou upozorňuje na jej rôznorodé historické vrstvy i intertextuálne vztahy s filmom a televíziou (filmové plagáty na stenách, nakrúcanie reklamy, práca protagonistky $\mathrm{v}$ dabingu).

Bratislava je však v kinematografii z prvého desatročia nového milénia často zobrazovaná aj v kontexte priamej či symbolickej konfrontácie so svetom vonku. Vo filme $O$ dve slabiky pozadu je vizuálne a kultúrne konfrontovaná s Parížom, ale aj s vlastným potenciálom kultúrnej a demografickej transformácie pod vplyvom pristahovalcov z Číny. Film Zostane to medzi nami sugeruje príklon k nadnárodnému charakteru mesta prostredníctvom špecifických, nadmoderných prostredí. Vo viacerých filmoch je konfrontácia so svetom vonku sugerovaná nie cez prostredie, ale cez postavy pristahovalcov a dočasných migrantov. Vo filme Polčas rozpadu prebieha konfrontácia stredoeurópskej skúsenosti so skúsenostami periférie bývalého východného bloku prostredníctvom postáv arménskych pristahovalkýň, ktorých existenčné a existenciálne problémy prepojené s vojnovými skúsenostami sa javia ako neporovnatelné s problémami priemerného 
bratislavského muža v strednom veku. Podobnú funkciu konfrontácie s neprenos-

nými skúsenostami plní aj postava migrantky z Macedónska vo filme Ženy môjho $m u z ̌ a$-vojnovej siroty na návšteve u známej herečky a moderátorky televíznej šou. Vo filme Tango skomármi prebieha konfrontácia česko-slovenských skúseností so skúsenostami rusínskych ekonomických pristahovalcov a migrantov z Ukrajiny. Na druhej strane, Nebo, peklo... zem sugeruje otváranie sa protagonistky možnostiam svetovej kariéry, ktoré prebieha paralelne s priznaním jej bratislavskej identity, čo je naznačené scénou stretnutia lokalizovaného pred fontánou v tvare zemegule pred bratislavským Prezidentským palácom. Vo viacerých mileniálnych filmoch sa však potreba prekročit' hranice mesta nespája len s potrebou rastu, no tiež s potrebou prekonania negatívnych javov života v meste. Protagonistka filmu Polčas rozpadu Mia sa predtým, než neštastnou náhodou zahynie, chce vrátit' do Spojených štátov, pretože zanedbávaná rodičmi a sklamaná milencom sa necíti byt' v Bratislave doma. Rádio Európa z filmu Vadí nevadí zas predstavuje únik do virtuálneho sveta kozmopolitizmu a umenia v kontexte mesta pretkaného mafiou a vyhorenými policajtmi, ktorí sa tešia už iba na dôchodky. Častým javom v mileniálnych mestských filmoch sú rozpadnuté či rozpadajúce sa manželstvá, rozmach kriminality, problémy spojené s neverou.

Potreba prekročit' hranice mesta je teda prítomná už vo filmoch, ktoré sa Bratislave venujú priamo, ale prenáša sa aj do postupného opúštania či redukcie bratislavských lokalít - počnúc napríklad filmami Démoni a Pokoj v duši a pokračujúc filmami ako Attonitas (réžia Jaroslav Mottl, 2012) či Babie leto (réžia Gejza Dezorz, 2013), v ktorých je Bratislava jednoducho vymenená za reálie iných slovenských miest, v tomto prípade Banskej Bystrice a Košíc. Tým sa otvára cesta k rozmanitejšej škále prostredív druhej dekáde nového milénia, kedy však Bratislava stále ostáva kulisou vybraných filmov využívanou takými rôznorodými spôsobmi, aké sa uplatňujú vo filmoch Lóve (réžia J. Kroner, 2011), Tigre v meste (réžia Juraj Krasnohorský, 2012), Červený kapitán (réžia Michal Kollár, 2016), Ostrým nožom (réžia Teodor Kuhn, 2019), Únos (réžia Mariana Čengel Solčanská, 2017) a Sviňa (réžia M. Čengel Solčanská - Rudolf Biermann, 2020).

Štúdia je výstupom grantového projektu VEGA 2/0025/21 Podoby slovenskej audiovizuálnej tvorby v súvislostiach neskorého socializmu. Zodpovedný riešitel: doc. Mgr. Jana Dudková, PhD. Doba riešenia: 2021 - 2023. Práca bola podporená štipendiom Nadácie Bratislava.

\section{Literatúra}

AUGÉ, Marc [OŽE, Mark], 2005. Nemesta. Prilog antropologiji nadmodernosti. Beograd: Biblioteka XX vek. ISBN 86-7562-038-1.

DUDKOVÁ, Jana, 2011. Slovenský film vére transkulturality. Bratislava: VŠMU - Drewo a srd. ISBN 978-80-89439-13-3.

FOUCAULT, Michel, 2003. O jiných prostorech. In Myšleni vnějšku. Praha: Hermann \& synové, s. 85-86. ISBN 80-239-2454-0.

GOTTDIENTER, Mark-BUDD, Leslie, 2005. Key Concepts in Urban Studies. London-Thousand Oaks - New Delhi: Sage Publications. ISBN 978-0761940982.

JAMESON, Fredric, 2016. Postmodernismus neboli kulturnílogika pozdního kapitalismu. Praha: Rybka Publishers. ISBN 9788087950272.

MALÍČEK, Juraj, 2004. Pop po domácky. Slovo, č. 9, s. 16. ISSN 1335-7492. 
336 MAZIERSKA, Ewa - RASCAROLI, Laura, 2003. From Moscow to Madrid. Postmodern Cities, European Cinema. London - New York: I. B. Tauris. ISBN 1-86064-851-7.

ŠMATLÁK, Martin, 2008. Hladanie vlastnej cesty. Kino-Ikon, roč. 12, č. 1, s. 135-147. ISSN

1335-1893.

হั)

\section{Filmografia}

$\overbrace{0}^{n} \quad$ Attonitas (réžia Jaroslav Mottl, 2012)

ง Až do mesta Ǎ̌ (réžia Iveta Grófová, 2012)

을 Babie leto (réžia Gejza Dezorz, 2013)

Bratisavafilm (réžia Jakub Kroner, 2009)

Čas grimás (réžia Peter Dimitrov, 2009)

Červený kapitán (réžia Michal Kollár, 2016)

Dážd'padá na naše duše (réžia Vladimír Balco, 2002)

Démoni (réžia Robert Šveda, 2007)

Dom (réžia Zuzana Liová, 2011)

Eva Nová (réžia Marko Škop, 2015)

Hana a jej bratia (réžia Vladimír Adásek, 2001)

Hazard (réžia Roman Petrenko, 1995)

Koza (réžia Ivan Ostrochovský, 2015)

Lištičky (réžia Mira Fornay, 2009)

Lóve (réžia Jakub Kroner, 2011)

Malé oslavy (réžia Zdeněk Tyc, 2008

Môj pes Killer (réžia Mira Fornay, 2013)

Na krásnom modrom Dunaji (réžia Štefan Semjan, 1994)

Nebo, peklo... zem (réžia Laura Siváková, 2009)

O dve slabiky pozadu (réžia Katarína Šulajová, 2004)

Ostrým nožom (réžia Teodor Kuhn, 2019)

Pokojv duši (réžia Vladimír Balko, 2009)

Polčas rozpadu (réžia Vladimír Fischer, 2007)

Sviňa (réžia Mariana Čengel Solčanská - Rudolf Biermann, 2020)

Tango s komármi (réžia Miloslav Luther, 2009)

Tigre v meste (réžia Juraj Krasnohorský, 2012)

Únos (réžia Mariana Čengel Solčanská, 2017)

Vadí nevadí (réžia Eva Borušovičová, 2001)

Vel'ký rešpekt (réžia Viktor Csudai, 2008)

Vtáčkovia, siroty a blázni (réžia Juraj Jakubisko, 1969)

Zázrak (réžia Juraj Lehotský, 2013)

Zostane to medzi nami (réžia Miroslav Šindelka, 2003)

Ženy môjho muža (réžia Ivan Vojnár, 2009)

Doc. Mgr. Jana Dudková, PhD.

Ústav divadelnej a filmovej vedy

CVUSAV

Dúbravská cesta 9

84104 Bratislava

Slovenská republika

E-mail: janadudkova@gmail.com 